\title{
Can Decentralisation of Structures and Devolution of Governance Power Enable an Effective Response to COVID-19 Disruptions? Lessons from the South African Education System
}

\author{
Thamsanqa Thulani Bhengu \\ ORCID iD: https://orcid.org/0000-0001-6777-4279
}

\begin{abstract}
Globally, scholarship around decentralised structures and devolved governance powers has been credited for 'giving power to the people'. Power to make governance decisions goes with ownership of those decisions and accountability to multiple stakeholders. Therefore, it is not surprising that when South Africa became a democracy, it adopted some form of decentralisation of management and governance structures and devolution of power as part of its transformation agenda. However, through its own policies, the Department of Basic Education (DBE) has not successfully implemented this agenda in any meaningful way. In this conceptual paper, I examine various education policies which I argue have, paradoxically, promoted and entrenched inequalities of the past, and continued to disempower many schools. I also draw from current local and global literature to show that while decentralisation has succeeded to some extent, devolution of power has not. Concomitantly, schools with real devolution of governance powers stand a better chance of providing an effective response to disruptions caused by the coronavirus disease (COVID-19) pandemic.
\end{abstract}

Keywords: school governance, decentralisation, devolution of power, school-based management, structural change, inequalities. 


\section{Introduction and Background}

... leaders of some regimes in Asia and Africa, view decentralization as a substitute for democracy, and a safe way to acquire legitimacy and grassroots support (Naidoo 2002: 3).

The above extract illustrates some challenges, complexities and contradictions surrounding conceptions and applications of devolution and decentralisation. The main message is that the devolution of power to the grassroots, through the government's decentralisation efforts, is a subject of debates and controversies. At the heart of this complaint is the perennially perceived challenge of cosmetic changes in the education system which scholars like Jansen (2001) call symbolism. The emergence of the coronavirus disease (COVID-19) pandemic has called into question the efficacy of structural reforms through decentralisation and devolution of powers to local levels, at least in the majority of the schools that were historically underprivileged, and still remain deprived to a large extent. For instance, decentralisation in South Africa does not, for example, seem to have addressed previous challenges of non-participation of local stakeholders in any meaningful way in tackling issues of redress and inequalities of the past. One reason for this failure in South Africa and other developing countries relates to a complex mix of contextual factors including skills deficits and capacities to exercise devolved powers (Kali 2020; Kuhon 2020; Lavonen 2017; Mncube 2009). In fact, the emergence of COVID-19 and the resultant national shutdown of the country 'exposed deep divisions between black and white, rich and poor that persists in the South African education system, a quarter century after the end of white minority rule' (Toyana 2020: 1). Similar sentiments are shared by Black et al. (2020), as well as other scholars. For instance, Dube (2020) highlights that during the national hard lockdown in South Africa, as part of the government's response to the COVID19 outbreak, the majority of schools in rural areas could not access the online learning that their privileged counterparts enjoyed. The devastating effects will be extremely difficult to reverse, especially in the less developed countries that De Falco (2020: 215) refers to as the 'Global South'.

One of the structural innovations of the education system adopted by the South African government when it assumed power in 1994, was to 


\section{Thamsanqa Thulani Bhengu}

devolve governance powers to local levels (Carrim 2001; du Plessis 2020; Pampallis 1998; Steyn et al. 2001). This was based on the belief that democratic participation of citizens would be promoted (du Plessis 2020; Kali 2020; Mollootimile \& Zengele 2015). It was also believed that bringing decision-making power to the grassroots would engender swift responses to their needs in times of turbulence such as those caused by COVID-19 (Netolicky 2020; O’Connell \& Clarke 2020). Decentralisation of structures and devolution of power are provided for in the South African government's legal and policy framework - Interim Constitution, Act No. 200 of 1993, the Constitution Act, No. 108 of 1996 and the South African Schools Act, No 84 of 1996, henceforth, the Schools Act (Republic of South Africa (RSA) 1996a; b).

Notions of decentralisation and devolution of power are complex and have no monolithic meaning (Cabral 2011). Decentralisation and the devolution of powers is usually associated with two principles of subsidiarity and ownership (Hammad 2013; Main 2017). The former refers to the belief that the closer the decision is to the affected people, the better the decision will be, while the latter refers to the commitment that people give to the decision (Kali 2020; Mollootimile \& Zengele 2015; O’Donohue \& Dimmock 1997). It is evident that the legal framework - the South African Constitution and the Schools Act, aimed, inter alia, at transforming the South African society (du Plessis 2020); and providing increased productivity at school level (Mollootimile \& Zengele 2015). However, empirical evidence about the success of decentralisation and school-based management, particularly in developing countries is less certain (Mollootimile \& Zengele 2015). Besides ensuring stakeholder participation in decision-making, no changes occurred, and inequalities of the past persisted (Davids 2020; Hammad 2013; Kuhon 2020; Moorosi et al. 2020). In that regard, Chikoko (2009) cautions us against a simplistic attitude towards decentralisation as it is not a panacea for all school decisional problems. Notions of decentralisation are complex, and some of the complexities emanate from a lack of evidence of direct and automatic connection between it and improved quality of education (Davies et al. 2003; du Plessis 2020; Netolicky 2020). This includes skills to provide an effective response to emergencies such as the COVID-19 pandemic (Kali 2020; Netolicky 2020). Nevertheless, what is important is that during times of crises such as that of COVID-19, leaders need to act swiftly and with foresight as they seek the best possible options (Netolicky 2020). 
In the South African context, decentralisation took place as part of the new government's democratisation process that was driven by the African National Congress (ANC) (Heystek 1997). This scholar and others highlight that decentralisation empowers educators and communities at local level (Heystek 1997; Heystek \& Emekako 2020; Kali 2020). While decentralisation enjoys credit among scholars, evidently it is not without challenges. The merits underlying the motives for decentralisation of education management structures are highly contested and debates on this take three strands. First, decentralisation efforts empower local structures/stakeholders to make appropriate and context relevant decisions (Giles 1998; Kali 2020; Lavonen 2017). This position assumes that the decentralisation concept goes together with the concomitant term of devolution of power to make decisions on substantive issues. However, reality suggests that this assumption is not always true (Giles 1998; Kali 2020; Kuhon 2020). Therefore, it is clear that decentralisation without devolution has little meaning (Kali 2020). Stakeholders at local level need to enjoy some powers and have capacity (Lavonen 2017) to act on their legislated mandates. The second strand has strong conspiratorial undertones in the argument that decentralisation is just a ploy by the government to shift the blame for its service delivery failures to those at grassroots level, whose capacities to deliver on their mandates may be questionable (Sayed 1997). The third strand is closely linked to the first in that it advocates a neoliberalist ideology. This ideology describes decentralisation and devolution as a means to shift power away from the government at national level to the local stakeholders. One of the major assumptions undergirding this position is that local communities have the capacity to carry out their legislative mandates (Cheng \& Cheung 2008; du Plessis 2020; Lunenburg 2010; Mokoena 2011; Mollootimile \& Zengele 2015; Wadesango et al. 2010), whereas, this has consistently proven to be complex and questionable, and thus may be unworkable (Dunn 2020; Giles 1998). The title and the content of this paper is cast in ways that foreground such conceptual debates and conundrums.

This is a conceptual paper which interrogates the notion of decentralisation and devolution of power making impactful decisions at school level, and its efficacy for providing an effective response to the outbreak of the COVID-19 pandemic. The paper adds to the debates about structural reforms in education and devolution of power in South Africa. Additionally, such debates explore the complexities of decentralisation and 


\section{Thamsanqa Thulani Bhengu}

possible efficacies for schools' responses to turbulent environments such as those posed by COVID-19 pandemic. This discussion acknowledges and foregrounds a complex interplay between decentralisation of structures and devolution of power in effective governance responses to crises, particularly the COVID-19 disruptions. Policy discourses are inherently complex, complicated and fraught with contradictions and misunderstandings (Bayeni \& Bhengu 2018; Fournier et al. 2020; Hammad 2013). The South African situation is even more complex in the sense that policy development is not just about ensuring efficiency of service delivery as is the case with the developed economies of the world. However, decentralisation, as I highlight elsewhere in this paper, is also about transformation, equity and redress of past inequities (Bray 1997). For instance, issues of policy development in South Africa, given its historical context, were always fraught with differing expectations by the public. For example, those who were previously oppressed expected radical changes and those that had previously benefitted from the apartheid government's policies, expected little change from the system that had served them so well (Pandor 2001). I, therefore, argue that policy frameworks that have evolved since the advent of the democratic dispensation in South Africa have, unsurprisingly, tended to accommodate these differing expectations, and thus did very little to change the past inequities. Given this background, this discussion takes off with an explication of the South African policy context that directly relates to the problem, which also includes notions of structural decentralisation and devolution efforts of the government. The discussion then shifts to situate such discourses in the global contexts before closely interrogating specific policies which, I argue, contribute to remarkably unfair governance capabilities in South Africa. I then interrogate how decentralisation and devolution of powers to school level may have contributed to the manner in which schools (according to their various quintiles) responded to the COVID-19 pandemic, especially when schools were asked to reopen. The discussion that follows thereafter focuses on some key lessons we can draw from decentralisation and devolution within the policy environment.

\section{Contextualising the Problem}

The government's policy context in South Africa is predicated on its efforts to redress the imbalances of the past and enhance democratic participation at 
the grassroots level (du Plessis 2020; Kali 2020; Sayed 1997). Theoretically, decentralisation helps in improving governance through accountability and a high rate of responsiveness to the governed (Davids 2020; Teja 2020). However, efforts to develop and implement policies to redress such inequalities do not seem effective in achieving the intended outcomes. For instance, one of these efforts was to establish standard class sizes across public schools (De Groof \& Malherbe 1997). The then Department of Education (DoE) established a teacher: learner ratio as follows $-1: 35$ in primary school and 1:40 in secondary schools (Steyn et al. 2001). However, this has not happened in the majority of schools due to a number of factors, such as the limited classroom spaces. The funding model adopted by the then DoE did not sufficiently equip the majority of schools to effectively deal with class size challenges. Because of such deficiencies, financial capacities to address the problem of class size across the education system have been questioned both by the Department of Basic Education (DBE) and the DoE before it, regarding most schools in the country. In South Africa, 51\% of the children live in poverty (von Fintel et al. 2017) and attend $80 \%$ of underresourced public schools (Spaull 2013). Seventy percent of poor children attend no-fee schools (Taylor et al. 2019). Recent Education Management Information System (EMIS) statistics (DBE 2020) indicates that the number of quintile 1 - 3 schools has grown to $83 \%$, which implies that the number of under-resourced schools has not decreased and neither have the challenges associated with this phenomenon. These are schools that rely solely on funding by the DBE in terms of the Norms and Standards framework.

The funding formula has not resolved these challenges but seems to have contributed to the persistent phenomenon in the education system that Chikoko et al. (2015: 453) describe as a 'sad mixture of first world and third world institutions'. Therefore, the cycle of poverty continues in the sense that children from poor families continue to receive poor quality education in under-resourced schools (Van der Berg 2008). The DBE, as highlighted elsewhere in this paper, has initiated numerous programmes aimed at alleviating the negative effects of poverty and other social ills on learners in schools. These include the Amended National Norms and Standards for School Funding (RSA 2006; 2008) and the National Schools Nutrition Programme (NSNP). For example, the NSNP ensured that learners from poor households receive a nutritious meal at school daily, which the COVID-19 outbreak deprived them access to. The National Education Infrastructure 


\section{Thamsanqa Thulani Bhengu}

Management System (DBE 2018) document shows how much the DBE has done to improve the provision of various facilities and infrastructure in disadvantaged communities (DBE 2018). However, problems relating to physical resources persist and undermine efforts to respond to the COVID19 outbreak. The desperate situation faced by disadvantaged schools is captured by Veriava et al. (2017: 2) when they say:

Without resources such as adequate infrastructure or equipment, textbooks and teachers, historically disadvantaged schools continue to exist and function at sub-optimal levels.

Nzimakwe and Jili (2020: 174) warn that the devastation caused by the COVID-19 pandemic may see many people trapped in 'extreme poverty because of a Global crisis, while the number of people living in hunger in the world might rise'. School principals have also experienced high levels of stress (Fournier et al. 2020). In this scenario, hunger and overcrowding exist side by side with affluence (Chikoko et al. 2015). It is almost unimaginable that no-fee schools (quintiles 1-3) can sufficiently address COVID-19 related challenges. Ex-Model $\mathrm{C}$ and independent schools have strong financial and physical resource bases (Ngulube 2019) which put them in a better position to adhere to COVID-19 health protocols which require 20 learners per teacher in the classroom (Department of Public Service and Administration (DPSA) 2020). The same cannot be said of their counterparts in quintile 1-3 schools as Toyana (2020) observed. This is mainly because these schools already had the capacity to do so. Through the additional functions provided in Section 21 of the Schools Act, these schools already have the power to appoint extra teachers using the financial resources provided for in the Schools Act. For example, the DBE Report (DBE 2019) indicates that there is a mixture of positive and negative stories. On one hand, it demonstrates laudable efforts by the government to financially support the majority of schools which fall within the first three quintiles, constituting $83 \%$ of public schools in the country. On the other hand, quintiles 4 and 5, constitute $17 \%$, with quintile 4 at $8 \%$ and quintile 5 at $9 \%$. The alarming part is that a huge majority of schools $(83 \%)$ are unlikely to be able to adequately respond to the demands of decentralisation and devolution, and this suggests the enormity of the challenge of schools' financial sustainability. It is also in the same category of schools that underperformance is experienced (Choi \& Gil 2017). Issues of structural reform and the devolution of power are a worldwide phenomenon, which I address next. 


\section{Decentralisation and Devolution of Power: International Perspectives}

Structural reforms in schools are called different things in different countries. For example, in England and Wales, it is known as 'Local Management of Schools'; in Scotland, it is called 'Devolved School Management', while in North America, it is known as 'School-Based Management or Site-Based Management' (Levačič 1995). In Australia and New Zealand, it is referred to as School-Based Management or sometimes Self-Managing schools (O’Donohue \& Dimmock 1997). Many countries in Africa, including South Africa, have used the term School-Based Management, including South Africa (Prew, 2018; Department of Education, 1996). While decentralisation of structures and devolution of powers have been regarded by some as two sides of the same coin, it has unfolded differently in different contexts. Nevertheless, there is broad agreement among scholars about its efficacy which is based on two key principles of 'subsidiarity' - the closer the decisions are to the people who stand to benefit from them, the higher their commitment to 'ownership' is going to be (Caldwell \& Spinks 1998; Kali 2020; Lavonen 2017; Levačič 1995; O’Donohue \& Dimmock 1997). Dominant narratives in the context of developed economies are largely about the enhancement of service delivery rather than anything else compared to the situation in South Africa where issues of societal transformation and redress are at play (du Plessis 2020; Sayed 2001).

The motives for devolution have also been questioned. For example, Hargreaves (1994) avers that in England and Wales, the impact of Local Management of Schools has been that instead of improving the capacities of educators and schools to engage willingly in planning and improvement, reforms have increasingly manipulated educators to fulfil the government's agendas. Similar sentiments have been expressed locally and elsewhere in the world where scepticism about the government's decentralisation motives are raised (Kulipossa 2004; Sayed 1997). Scholars believed that the then DoE may have tricked local stakeholders into buying into (and taking responsibility for) the government's failures (Sayed 1997). Research in the United Kingdom and elsewhere has shown that the mere decentralisation of authority and responsibility from the central government offices to the schools is no guarantee that schools will be more efficient (Caldwell \& Spinks 1998). Surely, there are many other factors that come into play if 
quality education is to be assured. Structural changes per se neither encourage innovation and quality nor stifle them. Nevertheless, what is clear is that decentralisation can create opportunities or remove obstructions because what happens within organisations at a local level depends on the people at the grassroots (du Plessis 2020; Kulipossa 2004; Mollootimile \& Zengele 2015). These debates find resonance with the situation in South Africa as well, where mere decentralisation and devolution cannot be assumed to bring about the desired changes, however noble such changes might be. For instance, in their systematic review of literature on school governance, from 1996 to 2016, Moorosi et al. (2020) argue that although the government attempted to bring about social change, issues of social justice did not underpin such efforts. Implied in their analysis is that social injustices of the past remain unresolved, as I argue in this paper. Adding to the structural changes debate, du Plessis (2020) dispels the popular view of bipolarising the decentralisation and centralisation concepts. Instead, du Plessis (2020) advocates for a compromise whereby the two concepts should not be viewed as opposites.

\section{Decentralisation and Devolution of Power: South African Policy Context}

Previous sections have reflected on key debates which focus on the concepttualisation and efficacies of structural reforms through decentralisation and devolution. There are numerous pieces of legislation that underpin structural, governance and financial arrangements of public schools in South Africa, and these are the South African Constitution, Act No. 108 of 1996, (RSA 1996a), the National Education Policy Act, No. 27 of 1996, (RSA 1996b), the Integrated School Health Policy (2012), National Schools Nutrition Programme (DoE 2009) and the Schools Act (RSA 1996c). As highlighted in my opening remarks about the thesis of this paper, structural decentralisation and devolution of power is provided for in South Africa's Constitution and other related legislation such as the Schools Act. As part of the government's structural decentralisation and broad education transformation agenda, Section 5 and subsequent sections of the Schools Act, place the governance and management of public schools at local level and give the School Governing Bodies (SGBs) differentiated governance powers (du Plessis 2020; Heystek 2011; Mncube 2009; Pampallis 1998). While 
acknowledging the SGB's role in ensuring quality education provision and promoting democratisation in schools, Heystek (2011) highlights various negative factors that militate against them realising their legislative mandates. For instance, all public schools, through SGBs, have the powers to adopt the constitution and mission statement of a school; administer and control the school's property, buildings, grounds, including renting them out for fundraising purposes, to name but a few.

There are also additional functions for which SGBs can apply. For example, SGBs may apply to the Provincial Education Department to be allocated additional functions, which include the right to maintain and improve the school's property, buildings and grounds, determine extracurricular activities and choose the subject options offered at the school (Steyn et al. 2001). The SGBs also have powers to employ teachers in addition to those allocated and paid for by the Provincial Education Department, as long as the funds to pay for such teachers are raised by the schools. However, despite the devolved powers given to the SGBs, not all public schools enjoy these powers as the 2019 EMIS statistics (DBE 2019a) suggest that the majority ( $83 \%$ ) of public schools belong to quintiles $1-3$ and are thus declared 'no-fee' schools (DBE 2020). Figure 1 clearly show this reality. Therefore, the efficacy of decentralisation is not without contestation, and such a reality is acknowledged globally, as I have highlighted in previous sections. The next few paragraphs provide a detailed account of why the notion of decentralisation enjoys support from all political spectrums for both historical and philosophical reasons.

It is interesting to note how and why two opposing ideologies, one representing the apartheid establishment and the other the liberation movement, represented mainly by the ANC, both found themselves coalescing on the need for decentralisation. Pampallis (1998) describes such a coalescence as serving the interests of both traditions with one section fighting to retain the privileges and the other hoping to encourage decisionmaking processes for local communities that had been marginalised for a long time. This is how he explains this view:

There was the tradition of Model C schools, introduced by the National Party government into almost the entire white state school system in 1992. Partly, this was a response to the state's growing inability to provide the same level of financial support to the white 


\section{Thamsanqa Thulani Bhengu}

schools as previously, and partly, it was an attempt to ensure continued control by white local communities as opposed to the schools falling into the hands of a democratically elected government (Pampallis 1998: 168 - 169).

From this perspective, it is evident that decentralisation can give people powers to make decisions, one of which could be to preserve the status quo rather than to facilitate change. To express the second perspective which provides a foment for decentralisation, Pampallis (1998: 168) says:

The democratic movement had, since the mid-1980s, been demanding the establishment of Parent-Teacher-Student Associations (PTSAs) as a means of getting the schools (which had been disrupted by anti-apartheid resistance) to function properly by putting them under the control of school communities.

The above two extracts indicate that for different reasons, decentralisation was conceptualised to achieve some form of power within local communities. At least two lessons can be learnt from the two positions, the first being the centrality of community participation in the education of the children and the perceived concomitant powers that they stand to enjoy. Second, there seems to be a blurring of philosophical beliefs and values regarding decentralisation, devolution and community participation, as suggested by scholars such as Grant-Lewis et al. (2000), Pampallis (1998) and others.

In a documentary analysis study conducted by Grant-Lewis et al. (2000), these scholars conceptualised decentralisation as emanating from modernisation and neo-liberalism. Grant-Lewis et al. (2000) have pointed to several assumptions on which the government seems to have based its notion of participation and devolution of powers to local schools. In the main, there are six assumptions whose credibility these scholars caution about; and they are as follows:

(a) Communities are homogeneous, and with the demise of apartheid they are relatively independent from the post-colonial state and global capitalism. (b) Participation is divorced from politics. Therefore, it is assumed that communities are to be united as well 
as homogenous; thus, participation is an all-inclusive process, and not an elitist one. Decision-making regarding school governance is consensual, and not contentious. Grant-Lewis et al. (2000) feel that such a position denies communities their political lives, and democracy is equated with acceptance, and not debate.

(c) Participation is a positive intervention that will improve schools due to the 'subsidiarity' and 'ownership' principle - greater local participation will improve the relevance, quality and accountability of schools.

(d) Schools, parents and other community members are receptive to taking on new responsibilities. All three assumptions are not equally applicable across communities.

(e) Participation is a rational and morally correct act. The argument here is that given the expected benefits of increased local participation, it makes sense for local participants to participate actively. To do otherwise would have been irresponsible and irrational.

(f) Financial deficiency can be resolved by community participation. Communities are assumed to be able to mobilise their own resources. Equity can be achieved by devolving financial responsibility for basic education to the local level.

All these assumptions come from a neo-liberal framework (Grant-Lewis $e t$ al. 2000) and do not reflect the true realities in the majority of schools and communities. The next section pays particular attention to the South African realities in terms of school profiles and potential feasibility in providing effective responses to the COVID-19 outbreak health protocols.

\section{Decentralisation, Devolution of Power and the Implications for Effective Responses to Emergency Situations}

This section outlines the profile of South African schools and explores their 


\section{Thamsanqa Thulani Bhengu}

potential capacity to effectively respond to the effects of the COVID-19 pandemic on schooling. In interrogating efficacies and implications of decentralisation, no attempt is being made to provide easy answers and solutions to complex problems such as those posed by the COVID-19 outbreak, as this pandemic has enormous effects on schooling as we know. Scholars such as Black et al. (2020), Obiakor and Adeniran (2020), Di Pietro et al. (2020), Harris (2020), as well as Spaull and van der Berg (2020), highlight the devastation that COVID-19 caused to the learners, parents, teachers, school administrators, and wider community. Harris (2020) states that COVID-19 disrupted schooling worldwide. Globally and nationally, the main efficacy of decentralisation and devolution has been in its capacity to respond to challenges faced by schools at local levels, both quickly and effectively (du Plessis 2020; Grant-Lewis et al. 2000; Mollootimile \& Zengele 2015; O’Connell \& Clarke 2020). In the introduction, I indicated that devolution of powers may mean little if stakeholders at a local level do not have capacities to utilise powers in such a way that they can carry out their legislated mandate. Knowledge and skills to manage one's portfolios is important. That is why Section 19(a) and (b) of the Schools Act mandates the provincial Head of Department (HoD) and school principals using delegated powers from the HOD, to provide training for the SGBs once they are elected (RSA 1996c).

The Schools Act provides for all public schools in the country to have powers to do many things relating to governance and management (Pampallis 1998). However, such powers can only be exercised if schools have the capacity to do so. The reality in South Africa is that capacities to exercise powers are influenced to a large extent by the schools' location in the quintile system. The practice of putting public schools into five quintiles is an innovative strategy adopted by the DBE to allocate funds to schools in an equitable manner. In terms of this formula, the lower the quintile to which the school belongs, the bigger the share of allocated funds and vice versa (Bhengu \& Mkhize 2013). The irony of this exercise is that those schools in lower quintiles (quintiles $1-3$ ), were categorised as 'no-fee' schools and because of this, they do not have the additional powers that the wellresourced schools in quintile 5 enjoy. Figure 1 shows the distribution of schools in the country according to the quintile system, and this analysis is drawn from the EMIS data provided by the DBE for the fourth quarter of 2019. 


\section{Quintile Distribution}

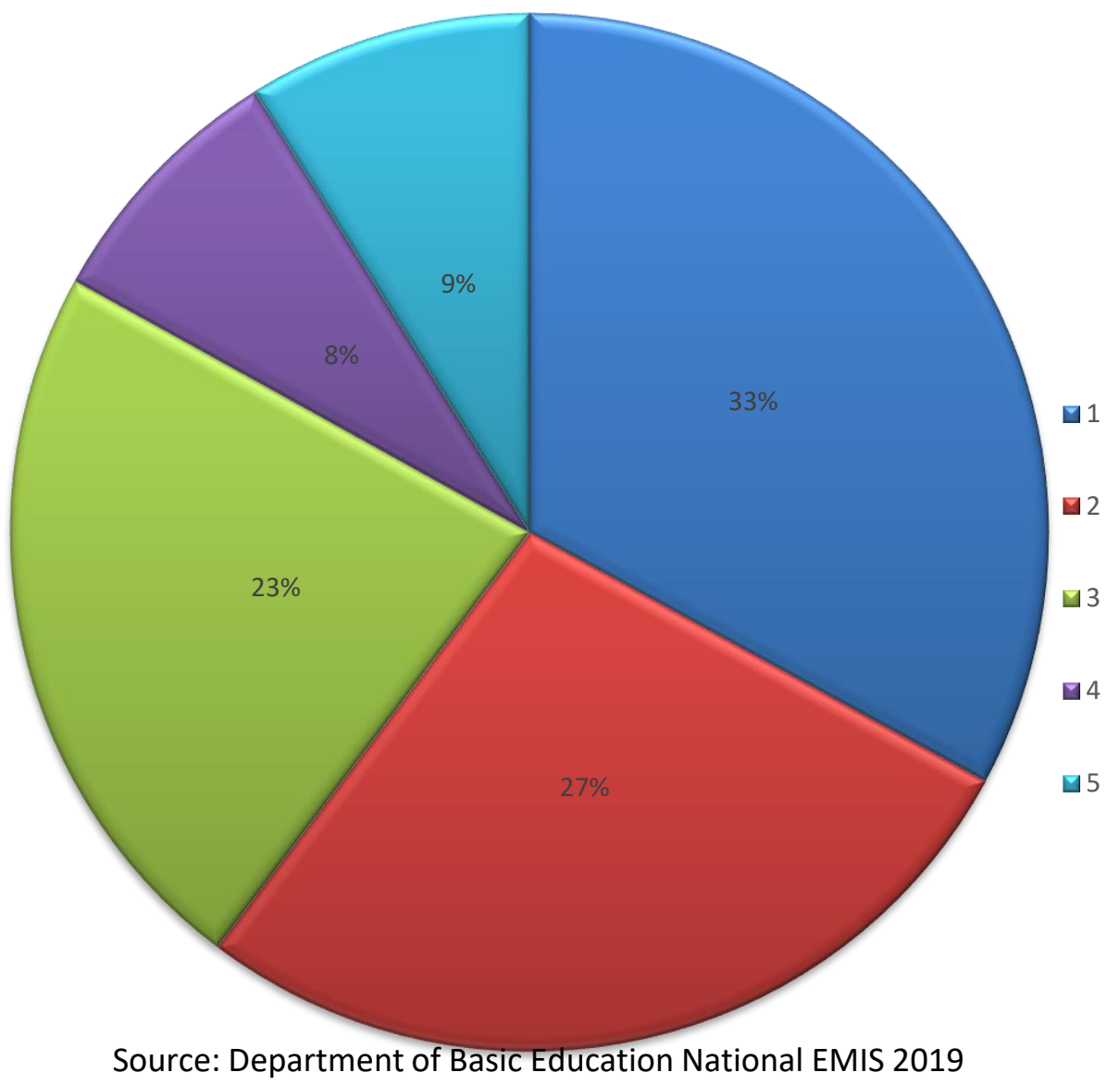

Figure 1: Distribution of public schools according to quintile ranking

Figure 1 shows the analysis of EMIS data (DBE 2019a) which indicates the distribution of schools within the five quintiles. This analysis indicates that out of 23068 public schools in South Africa, a large majority belong to quintiles $1-3(83 \%)$. Therefore, for them, devolution of powers within a 


\section{Thamsanqa Thulani Bhengu}

decentralised structural arrangement does not mean anything in terms of their financial standing and capacity to deal with their situation and emergencies. Only a tiny minority of schools - approximately 2046 schools (9\%) - are in quintile 5, and thus enjoy Section 21 functions allocated by the provincial HoD. They can raise their own funding and are the only schools, together with independent schools that have had the capacity to respond to the early COVID-19 disruptions. From these statistics, it becomes clearer that as much as the government has tried to lessen the financial burden that the majority of schools carry, past inequalities remain. This is so because schools in quintiles $1-3$ remain in a highly vulnerable financial position where they depend on the government for everything they do.

\section{The Nexus between the Schools' Profile (Categorisation) and their Responses to COVID-19 Pandemic Disruptions}

The discussion in the preceding sections has indicated that besides the decentralisation of structures, the devolution of power is conditional on a variety of factors such as the profiles of schools. It has also emerged from the discussion that the profiles of schools are closely related to the historical factors which put some schools in an advantageous position while the majority remain in an undesirable situation. The discussion in this section positions schools in quintile 5, which are commonly known as ex-Model C schools, as more capacitated to respond to COVID-19 pandemic disruptions. Ex-Model C schools are those schools in South Africa that were reserved for whites during the apartheid era, and they were sufficiently resourced compared to their black counterparts (Pampallis 1998). It is parents in these schools that were vehemently against school closures during national lockdown (Govender 2020). In making such arguments I am drawing, largely, from current literature, media and other documented reports.

Table 1 clearly shows the skewed nature of education provision in the country where a tiny fraction of schools is regarded as affluent because they have a sufficient supply of physical resources and serve a tiny minority of learners. On the other hand, a huge majority of schools are underresourced and service the majority of learners from poverty-stricken communities. As Spaull (2013) put it, $80 \%$ of schools in South Africa can be characterised as under-resourced, and lack much basic equipment, facilities and resources such as books, libraries, laboratories and other resources. 
When the DBE closed schools in March 2020 to curb the spread of COVID19 , it later announced universal health and safety protocols which it would apply when schools re-opened. Such health protocols were outlined in Circular 18 of 2020 (DPSA 2020). While schools were closed, learners dependent on school feeding schemes had no access to the nutritious food provided at school (United Nations Children's Emergency Fund (UNICEF 2020). The gravity of the disparities in our schooling became visible for all to see. For instance, in the media briefing held on 7th June 2020, Angie Motshekga, Minister of Basic Education, highlighted after consultation with stakeholders, 'All indications were that it would not be safe to start teaching and learning on the 1st of June' (Motshekga, SABC Briefing 2020). This statement indicated that the majority of schools were not ready to re-open at the expected time, bearing in mind that the majority of schools in South Africa are poor or under-resourced (quintile 1-3). She continued to state that: 'We also agreed on processes that were relating to independent schools, to small schools and schools for learners with special needs, that these schools should be managed differently'.

As I have mentioned elsewhere in this paper, a minority of schools, from the independent school and quintile 5 category, was ready and parents put pressure on the DBE to expedite schools' re-opening. This is evidence of disparities that persist between the rich and poor in our society. The COVID-19 pandemic laid bare the 'slow pace of government's efforts to eradicate poor sanitation infrastructure at some schools' (Khumalo 2020: 9). The extent of the infrastructure backlogs in Section 20 and Section 21 schools, which are largely located in quintile 1 and quintile 3 in the former category and quintile 5 in the latter, can be seen in the fact that a large sum of money had to be spent on temporary interventions such as mobile toilets and water tanks. For instance, Julia Chaskalson of Section 27, argued that 3 800 schools in South Africa had pit toilets (Khumalo 2020: 9). This is despite the fact that back in 2013, the DBE had published the Norms and Standards for School infrastructure, where it was stipulated that every school must have water, electricity, internet, working toilets, safe classrooms with a maximum of 40 learners, security, a library and sports facilities (Khumalo 2020). Had such an ambitious undertaking been implemented, statistics produced by Julia Chaskalson of Section 27 would not be the talking point it is. What is noteworthy is that seven years later (2020), the issue of sanitation in many schools remains a problem that has 
become a critical factor in determining whether schools reopen or not during the peak of the COVID-19 pandemic. According to Khumalo (2020), the DBE had to spend R800 million to provide water and mobile toilets across the country. What I find unbelievable is the fact that R1.7bn that had been budgeted for school infrastructure had to be reallocated to cover COVID-19 expenditure needs (Cyster, as cited in Khumalo 2020). Ex-Model C (quintile 5 ) schools on the other hand had wanted to open sooner rather than later due to their state of readiness.

The two categories of schools' response to the COVID-19 threat differed starkly. When COVID-19 cases occurred, quintile 5 schools, many of which were ex-Model C, and independent schools informed the Department of Health $(\mathrm{DoH})$ and then the circuit manager concerned, who immediately closed the school. For the rest of the day, the school concerned was sanitised by a sponsor (private) and the following day, operations (teaching and learning) would resume. Water and sanitation supply were not a challenge, and sanitiser stands had been provided for each classroom for learners to sanitise themselves. Even before the outbreak of COVID-19, some school classrooms had already been fitted with cameras for principals to monitor compliance with teaching and learning requirements.

\section{Lessons and Discussion}

This section about lessons that can be learnt has two segments. The first provides two broad areas of lessons and the second proposes a model that I believe can be considered by school-based leaders when dealing with complex issues affecting their schools. The first point delves into the notion of non-change in relation to schools' capacities to respond to factors that negatively affect them. The second lesson highlights the issue of a recurring need for human capital development which I believe is central to people developing capacities that enable them to exercise power that they all desire in order to provide effective responses to the schools' needs.

(a) 'The more things change; the more they stay the same!' (exploring the change and non-change in education after apartheid)

This section explores the notion of non-change by highlighting complexities associated with policy discourse, and how the reality of non-change finds expression in the manner in which schools and the public have responded to 
the COVID-19 pandemic. Jansen (2001) eloquently describes the phenomenon of non-change in education and situates it in numerous flawed assumptions about policy - practice discourses, particularly, from the perspectives of politicians and bureaucrats. Jansen (2001) raises three useful questions, whether the government always means what it says in its policy documents or not; whether the policy process always takes a linear format whereby policy intentions, as expressed in policy documents, are actually implemented as contemplated, without any mediation at the implementation stage. Thirdly, he questions the common conception of policy as the official ideal statement made by the government, and that it will be effectively applied at the implementation phase. These questions have also been raised by many other scholars (see Clegg 2010; Fournier et al. 2020; Fullan 2011; Kali 2020; Lungu 2001; Netolicky 2020; Soudien et al. 2001; Tabak 2006). These scholars caution against blind adherence to such views as they may create frustration for both policymakers and implementers when real change becomes elusive to attain. One of the challenges lies in the question that Jansen (2001: 271) raises when he asks, 'What if the policy stated was not in the first instance intended to change practice?' This resonates with the views expressed by Pampallis (1998) when he reflects on the origin of decentralisation in the context of the South African political landscape. Having said this, we should not be surprised to discover that the schools' responses to the COVID-19 pandemic have turned out as they have.

The response to the COVID-19 pandemic and the call by the DBE for schools to reopen revealed a stark contrast between schools across the quintiles, with the no-fee category opposed to it while those in quintile 5 welcomed it. This pitted schools and communities against one another and across the racial divides of the apartheid era. It highlighted the continuing disparities between the two socio-economic groupings and called into question the extent to which issues of redress, equity, equality and democracy that both the Constitution and the Schools Act cherish, are being realised.

\section{(b) Policy capacity, human resources development for effective policy implementation}

It has become clear from the discussion that there are numerous education policy implementation constraints that have hampered successful implementation and the institutionalisation of policies in order to achieve the intended outcomes. Commenting on the skills required by various 


\section{Thamsanqa Thulani Bhengu}

school-based stakeholders to meet the requirements of the new government policies, including the Schools Act, various scholars, locally and globally (Fournier et al. 2020; Kali 2020; Karlsson \& Pampallis 1998; Kuhon 2020), highlight the issue of a skills deficit and underscore the need for training. For schools to qualify for additional functions as contemplated in the Schools Act, they should demonstrate special skills to manage finances among others, and this is one of the weakest areas characterising schools in quintiles 1-3. The fact that the majority of public schools, as Figure 1 indicates, do not enjoy Section 21 powers which enable them to raise funds, procure materials and equipment efficiently and have financial stability, raises questions about their capacities to manage their finances efficiently. Financial skill deficits persist (Myende et al. 2020) in many schools, particularly poor schools in quintiles $1-3$ ). It appears that the DBE has not paid any particular attention to the need for provision of sustained training as contemplated in Section 19(a), (b) of the Schools Act.

\section{(c) Some leadership practices that can provide an effective response to unpredictable situations and change}

The discussion in this section highlights some pitfalls in assuming that structural changes can ipso facto bring about fundamental change to schools' operational efficiencies. I, therefore, propose a model that can assist leaders in dealing with changes in complex environments around the schools. For instance, while the learners are being kept at home because of the closure of schools, principals as school leaders can, together with their staff explore ways and means of ensuring that learners have access to both learning opportunities and the nutritious food provided through the NSNP. There are more than nine million children from schools in the quintile 1-3 category (DBE 2019b). I must hasten to say that the model I am proposing here is not meant to be an answer to all leadership challenges. Nevertheless, I believe that it can be a useful framework that can assist leaders in handling today's complexities. Scholars such as Chikoko (2009) have warned against regarding decentralisation and devolution as a panacea for all educational leadership problems. Therefore, the two principles of 'subsidiarity' and 'ownership', generally associated with the success of decentralisation and devolution efforts is not adequate in the absence of effective leadership (Netolicky 2020). Human capacities, including leadership skills are crucial. In that regard, the work of Dunn (2020) could be important as a framework 
for understanding how one can handle urgent crises such as the COVID-19 pandemic. This scholar proposes a dualistic framework known as 'Technical Problem and Adaptive Challenges'. Dunn (2020) defines a technical problem as a problem that can be resolved with existing knowledge and skills. Adaptive challenges, on the other hand entail 'moving beyond what we, as a school or individual, currently know, understand and do' (Dunn 2020: 32). It is evident that adaptable approaches are appropriate for schools and education in handling complexities, unpredictability and change. Pollock (2020) highlights that during COVID-19, the impact on principals' work depends on where their school is located.

The Technical Problem and Adaptive Challenges model put the two factors (technical problems and adaptive challenges) in a dichotomy to explain the distinctions between them.
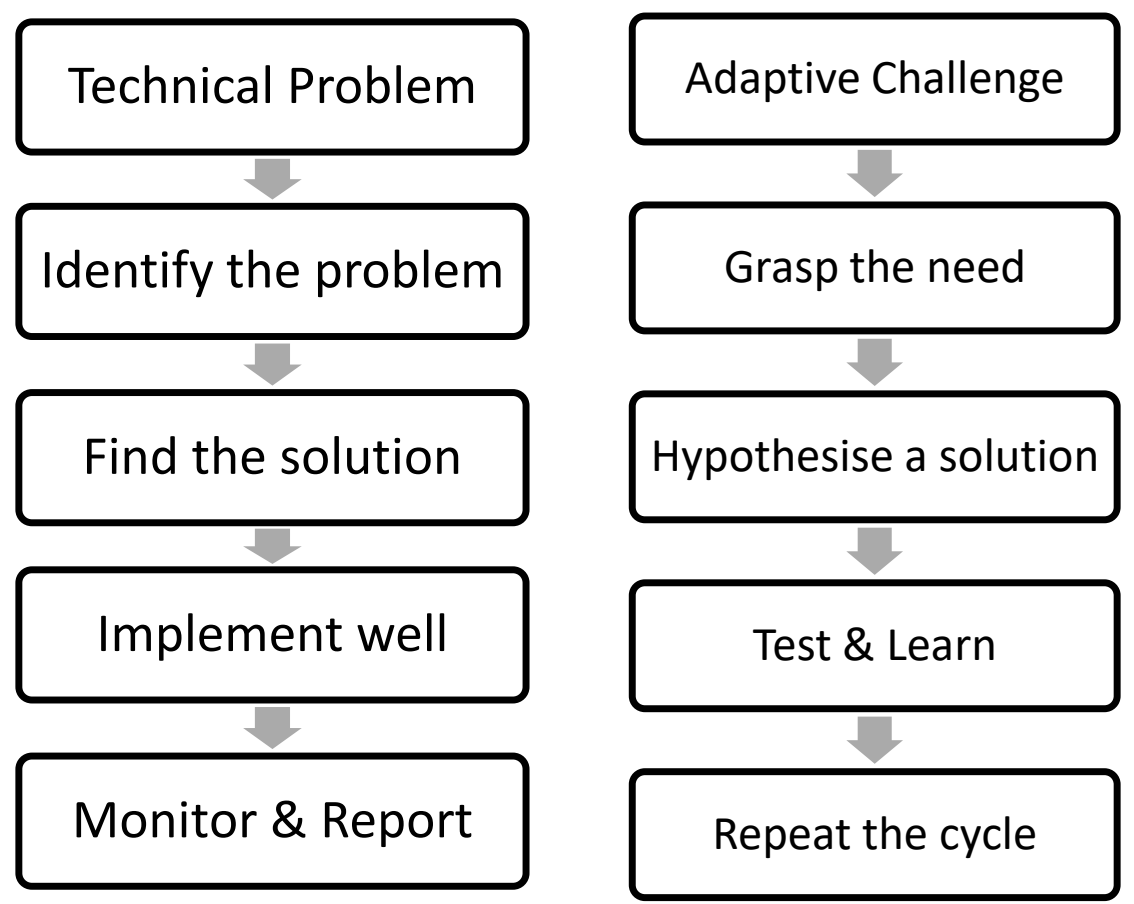

Figure 2 Technical Problems and Adaptive Challenges: Two different approaches (Dunn (2020: 32) 
The adaptive element is important in that it implores school leaders to move beyond what is currently known and understood (Dunn 2020). Furthermore, it is important to acknowledge that proposed solutions to current problems still have to be checked against what is known. This is an iterative process which highlights interconnections between technical problems and adaptive challenges. Hence, this model advocates a twopronged approach (Dunn 2020). In times of crises such as COVID-19, it becomes even more important that principals are aware of 'What they are doing and what they are learning from it' (O'Connell \& Clarke 2020: 4). Various scholars have explored and embraced this model (Dunn et al. 2019; Heifetz \& Laurie 1997), and it is implied that principals should be able to have some autonomy and other capacities to implement internally generated solutions. Figure 2 summarises the process of technical problems and adaptive challenges respectively.

This model, through its arrows for both the technical problems and the adaptive challenges, thus suggests a one-way process of addressing emergent challenges. However, this does not present the complete picture. On the right side, it is evident that solution seekers engage with the situation and stakeholders, and learn before the best alternative solution is found, which is directly opposite to the actions presented on the left side of the model. The role of leadership becomes critically important for schools to respond to difficulties (Browne 2020).

\section{Conclusion}

Evidence from policy discourses, experiences narrated in the media platforms during various levels of the COVID-19 national lockdown and phased reopening of schools, highlights numerous critical issues relating to the profiles of schools. The first is that decentralisation per se, was not useful in enabling schools to respond to challenges posed by the COVID-19 pandemic. It, nonetheless, created an environment where schools could mobilise resources that would facilitate effective teaching and learning, even during difficult conditions posed by this pandemic. The school profile factor played a huge role in enabling effective responses to the COVID-19 pandemic, particularly in ensuring that schools could reopen and comply with health protocols. This means that schools with sustainable financial capital and efficient SGBs were able to comply with health protocols 
developed by the government. During the national lockdown effected in March 2020, minimal disruptions occurred in this category of schools as they were able to continue teaching and learning through online platforms. This does not mean that the efficacy of online teaching and learning is unquestionable. With the infrastructure available at school, and the profile of parents who send their children to these schools, they were able to continue learning, using a variety of methods and technological devices such as laptop computers and smartphones, aided by the availability of data coupled with minimal network disruptions. This could not be done by their counterparts who happened to be in the majority and had previously been subjected to education of the poorest quality.

When schools were instructed to reopen under the COVID-19 pandemic protocols, which restricted the number of learners per teacher to 20 per class, compliance was automatic in many schools in the ex-Model C school category. Therefore, such schools enjoy governance power to make impactful decisions and were able to respond effectively to COVID-19 pandemic health protocols. The same cannot be said about the majority of public schools in South Africa that do not belong to this category of schools.

I conclude by arguing that education policies accentuate educational inequalities along the lines of social class rather than race as was the case during the apartheid era. Those from privileged backgrounds continued to enjoy education of high quality comparable to any in the developed world, they continued to provide education even during the national lockdown necessitated by the COVID-19 pandemic, and thus experienced minimal disruptions. What can be learnt from a South African education system's perspective is that decentralisation and devolution have not enabled those schools and communities that were previously disadvantaged to provide effective teaching and learning. Therefore, the notion of non-change has been reinforced as policy initiatives aimed at redressing inequalities of the past have done very little to change the practical situation for the majority of schools.

\section{References}

Bayeni, S.D. \& T.T. Bhengu 2018. Complexities and Contradictions in Policy Implementation: Lived Experiences of Three School Principals 
in South Africa. SAGE Open 1 - 12.

https://doi.org/10.1177/2158244018792037

Bhengu, T.T. \& B.N. Mkhize 2013. Principals' Instructional Leadership

Practices in Improving Learner Achievement: Case Studies of Five

Secondary Schools in Umbumbulu Areas. Education as Change 17, 1:

33 - 47. https://doi.org/10.1080/16823206.2014.865989

Bray, E. 1997. The Legal Status of Schools in the New South African

Education System. In De Groof, J. \& E.F.J. Malherbe (eds.): Human

Rights in South African Education: From the Constitution Drawing

Board to the Chalkboard. Leuven, Belgium: Acco.

Black, S., C.A. Spreen \& S. Vally 2020. Education, Covid-19 and Care:

Social Inequality and Social Relations of Value in South Africa and the

United States. Southern African Review of Education 26, 1: 40 - 61.

Bellows, A. \& N. Zohdy 2020. Is the Coronavirus Catalyzing New Civic

Collaborations for Open Government? Washington, DC: Carnegie

Endowment for International Peace.

Browne, L. 2020. Effective School Leadership in Challenging Times: A

Practice-First, Theory-Informed Approach. New York: Routledge.

https://doi.org/10.4324/9780429197154

Cabral, L. 2011. Decentralisation in Africa: Scope, Motivations and Impact

on Service Delivery and Poverty. Working Paper. No. 20. London:

Overseas Development Institute.

Caldwell, B.J. \& J.M. Spinks 1998. Beyond the Self-Managing Schools.

London: The Falmer Press.

Carrim, N. 2001. Democratic Participation, Decentralisation and Educational

Reform. In Sayed, Y. \& J. Jansen (eds.): Implementing Education

Policies: The South African Experience. Cape Town: UCT Press.

Cheng, F. \& Y. Cheung 2008. An Outlier Study of Multilevel Selfmanagement and School Performance. School Effectiveness and School Improvement 13,3: 253 - 290.

https://doi.org/10.1076/sesi.13.3.253.3428

Chikoko, V. 2009. Educational Decentralisation in Zimbabwe and Malawi:

A Study of Decisional Location and Process. International Journal of Development 29, 201-211.

https://doi.org/10.1016/j.ijedudev.2008.05.003

Chikoko, V., I. Naicker \& S.E. Mthiyane 2015. School Leadership Practices that Work in Areas of Multiple Deprivations in South Africa. 
Educational Management Administration and Leadership 43, 3: 452 467. https://doi.org/10.1177/1741143215570186

Clegg, S. 2010. The State, Power, and Agency: Missing in Action in Institutional Theory? Journal of Management Inquiry 19, 1: 4 - 13. https://doi.org/10.1177/1056492609347562

Choi, A. \& M. Gil 2017. Does School Leadership Affect Student Academic Achievement? Chicago, IL: University of Chicago Press.

Davids, N. 2020. Governance in South African Schools: Democratic Advancement or Hindrance? Educational Management Administration \& Leadership 1741143220937306.

Davies, L., C. Harber \& C. Dzimadzi 2003. Educational Decentralisation in Malawi: A Study of Process. Compare: A Journal of Comparative and International Education 33,2: 139 - 154.

https://doi.org/10.1080/0305792032000070075

De Falco, R. 2020. Human Rights, Fiscal Policy and Economic Pluralism: Building Inclusive Recovery after COVID-19. Peace, Human Rights, Governance 4,2: 215-246.

De Groof, J. \& R. Malherbe 1997. Introduction. In De Groof, J. \& E.F.J. De Groof (eds.): Human Rights in South African Education: From the Constitution Drawing Board to the Chalkboard. Leuven, Belgium: Acco.

Department of Education 1996. Changing Management to Manage Change in Education. Report of the Task Team on Education Management Development. Pretoria: Department of Education.

Department of Education 2009. National Schools Nutrition Programme: A

Guide for Secondary Schools. Pretoria: Department of Education.

Department of Basic Education. 2018. National Education Infrastructure Management System. Available at: https://bit.ly/2MJn5bq (Accessed on 12 February 2021.)

Department of Basic Education 2019a. A 25 Year Review of Progress in the Basic Education Sector. Pretoria: Department of Basic Education.

Department of Basic Education 2019b. Education Management Information Systems. Quarter 4 of 2019. Pretoria: Department of Basic Education.

Department of Health and Department of Basic Education 2012. Integrated

School Health Policy. Pretoria: Department of Health and Department of Basic Education.

Department of Public Service and Administration 2020. State of Disaster 
COVID-19: Public Service Return to Work Guidelines after the Easing of the National Lockdown. Circular 18 of 2020. Pretoria: Government Printers.

Di Pietro, G., F. Biagi, P. Costa, Z. Karpiński \& J. Mazza 2020. The Likely Impact of COVID-19 on Education: Reflections Based on the Existing Literature and Recent International Datasets. JRC Technical Report. European Union. Available at: https://www.stock.adobe.com (Accessed on 05 February 2021.)

Dube, B. 2020. Rural Online Learning in the Context of COVID-19 in South Africa: Evoking an Inclusive Education Approach. Multidisciplinary Journal of Educational Research 10, 2: 135 - 157.

https://doi.org/10.17583/remie.2020.5607

Dunn, R. 2020. Adaptive Leadership: Leading Through Complexity. International Studies in Educational Administration 48, 1: 31 - 38.

Dunn R., J. Hattie \& T. Bowles 2019. Exploring the Experiences of Teachers Undertaking Educational Design Research (EDR) as a Form of Teacher Professional Learning. Professional Development in Education 45, 1: $151-167$.

https://doi.org/10.1080/19415257.2018.1500389

du Plessis, A. 2020. The Emergence of Decentralised Centralism in the South African Education Governance System. Journal of Southern African Studies 46,1: 165 - 183.

https://doi.org/10.1080/03057070.2020.1705618

Fournier, E., S. Scott \& D. Scott 2020. Inclusive Leadership during the COVID-19 Pandemic: How to Respond within an Inclusive Framework. International Studies in Educational Administration 48, 1: 17 - 23.

Fullan, M. 2011. The Six Secretes of Change: What the Best Leaders Do to Help their Organisations Survive and Strive. Hoboken: Jossey-Bass. Govender, P. 2020. Former Model C schools 'Revolt' against School Closures. NEW EDUCATION. Available at:

https://www.timeslive.co.za/sunday-times/news/2020-07-26-formermodel-c-schools-revolt-against-closure/ (Accessed on 06 February 2021.)

Giles, C. 1998. Control or Empowerment: The Role of Site-Based Planning in School Improvement. Educational Management and Administration 26, 4: 407 - 414. https://doi.org/10.1177/0263211X98264006 
Grant-Lewis, S.G., J. Naidoo \& E. Weber 2000. The Problematic Notion of Participation in Educational Decentralisation: The Case of South Africa - A Report on the Implementation of the South African Schools Act. Johannesburg: University of Witwatersrand.

Hargreaves, A. 1994. Changing Teachers, Changing Times: Teachers Work and Culture in the Post-modern Age. London: The Cassell.

Hammad, W. 2013. The Rhetoric and Reality of Decentralisation Reforms: The Case of School-Based Management in Egypt. International Studies in Educational Administration 41, 2: 33 - 47.

Harris, A. 2020. Leading a School during Lockdown. Available at: https://my.charted.college/2020/04/leading-a school-during-lockdown/ (Accessed on 7 February 2021.)

Heifetz, R.A. \& D.C. Laurie 1997. The Work of Leadership. Harvard Business Review 75: 124-134.

Heystek, J. 1997. The Role of the Community in School Governance. In De

Groof, J. \& E.F.J. de Groof (eds.): Human Rights in South African Education: From the Constitution Drawing Board to the Chalkboard. Leuven, Belgium: Acco.

Heystek, J. 2011. School Governing Bodies in South African Schools: Under Pressure to Enhance Democratisation and Improve Quality. Educational Management, Administration and Leadership.

https://doi.org/10.1177/1741143211406149

Heystek, J. \& R. Emekako 2020. Leadership and Motivation for Improved Academic Performance in Schools in Low Socio-economic Contexts. International Journal of Educational Management 34, 9: 1403 - 1415. https://doi.org/10.1108/IJEM-10-2019-0378

Jansen, J.D. 2001. Explaining Non-change in Education Reform after Apartheid: Political Symbolism and the Problem of Policy Implementation. In Sayed, Y. \& J. Jansen (eds.): Implementing Education Policies: The South African Experience. Cape Town: UCT Press.

Kali, M. 2020. Challenges and Prospects of Decentralisation in Lesotho. International Journal of Humanities, Arts and Social Studies 5,2: 11 20.

Karlsson, J. \& J. Pampallis 1998. The Role of Governance Structures in the Sustainability of Learning Spaces. In: Ramsay, M. (ed.): Democratic Governance of Public Schooling in South Africa. Durban: Education Policy Unit, Natal. 
Khumalo, K. 2020. 'Human Dignity Costs Millions' - Education. Sunday World 30 August 2020.

Kuhon, R. 2020. Decentralisation and Education for all in Indonesia. POLYGLOT: Journal IImiah 16, 1: 14 - 33.

https://doi.org/10.19166/pji.v16i1.1996

Kulipossa, F.P. 2004. Decentralisation and Democracy in Developing Countries: An Overview. Development in Practice 14, 6: 768 - 779.

https://doi.org/10.1080/0961452042000284003

Lavonen, J. 2017. Governance Decentralisation in Education: Finnish Innovation in Education. Revista de Educación a Distancia (RED) 53,

1: 1 - 22. https://doi.org/10.6018/red/53/1

Levačič, R. 1995. Local Management of Schools, Analysis and Practice.

Buckingham-Philadelphia: Open University Press.

Lunenburg, F.C. 2010. The Decision-making Process. National Forum of Educational Administration and Supervision Journal 27,4: 2 - 12.

Lungu, G.F. 2001. The Educational Policy Process in Post-apartheid South Africa: An Analysis of Structures. In Sayed, Y. \& J. Jansen (eds.): Implementing Education Policies: The South African Experience. Lansdowne: UCT Press.

Main, O. (ed.). 2017. The National Government Handbook: South Africa 2017: A Complete Guide to National Government in South Africa. Pretoria: Yes Media. Available at:

https://issuu.com/yesmedia/docs/national_government_handbook_201

$\underline{7}$ (Accessed on 05 February 2021.)

Mncube, V. 2009. The Perceptions of Parents of their Role in the Democratic Governance in South Africa. Are they on Board? South African Journal of Education 29: 83 - 103. https://doi.org/10.15700/saje.v29n1a231

Mokoena, S. 2011. Participative Decision-making: Perceptions of School Stakeholders in South Africa. Journal of Social Sciences 29,2: 119 131. https://doi.org/10.1080/09718923.2011.11892962

Mollootimile, B. \& T. Zengele 2015. The Advent of School Based Management in the $21^{\text {st }}$ Century. Journal of Social Sciences and Humanities 10, 2: 172-184.

Moorosi, P., B. Bantwini, I. Molale \& N. Diko 2020. School Governance and Social Justice in South Africa: A Review of Research from 1996 to 2016. Education as Change 24: 1-23.

https://doi.org/10.25159/1947-9417/7994 
Motshekga, A. 2020. SABC Basic Education Department Media Briefing on Readiness for the Reopening of Schools: 07 June 2020 [online].

Available at: https://www.youtube.com/watch?v=dqLNo4LhGLs (Accessed on 7 February 2021.)

Myende, P.E., T.T. Bhengu \& I.S. Kunene 2020. School Financial Management Development Programme for Eswatini Principals: Lessons, Challenges and Implications. South African Journal of Education 40, 4: 1 - 11.

https://doi.org/10.15700/saje.v40n4a2041

Naidoo, J.P. 2002. Education Decentralisation in Sub-Saharan Africa: Espoused Theories and Theories in Use. Paper presented at FrancoSouth African Conference on Education and Decentralisation, African Experience and Comparative Analyses, held in Johannesburg, June 2002.

Netolicky, D.M. 2020. School Leadership during a Pandemic: Navigating Tensions. Journal of Professional Capital and Community. Available at:

https://search.informit.com.au/fullText; $\mathrm{dn}=085245862132717$;res=IE LAPA (Accessed on 6 February 2021.)

Ngulube, B. 2019. School Libraries are a Must in Every Learning Environment: Advocating Libraries in High Schools in South Africa. In Handbook of Research on Advocacy, Promotion, and Public Programming for Memory Institutions. IGI Global.

https://doi.org/10.4018/978-1-5225-7429-3.ch016

Nzimakwe, T.I. \& N.N. Jili 2020. Policy Responses to the COVID-19 Crisis: Dependence on Local Government for Long Term Stability. Alternation Special Edition 32: 173-196.

https://doi.org/10.29086/2519-5476/2020/sp32a7

Obiakor, T. \& A. Adeniran 2020. COVID-19: Impending Situation Threatens to Deepen Nigeria's Education Crisis. Abuja: Centre for the Study of the Economies of Africa.

O'Connell, A. \& S. Clarke 2020. A School in the Grip of COVID-19: Musings from the Principal's Office. International Studies in Educational Administration 48, 2: 4 - 11.

O’Donohue, T. \& C.A.J. Dimmock 1997. The Principals' Contribution to Schools Restructuring Initiatives Aimed at Improving Teaching and Learning, (Exploring the Potential of the Edited Topical History 
Research Approach.) Educational Management and Administration. London, Thousand Oaks and New Delhi: SAGE.

https://doi.org/10.1177/0263211X97251004

Pampallis, J. 1998. Decentralisation in the New Education System: Governance and Funding of Schooling in South Africa 1992-1997. In Ramsay M. (ed.): Democratic Governance of Public Schooling in South Africa. Durban: Education Policy Unit Natal.

Pandor, N. 2001. The Role of the State in the Governance of the Education System. In Sayed, Y. \& J. Jansen (eds.): Implementing Education Policies: The South African Experience. Cape Town: UCT Press.

Pollock, K. 2020. School Leaders' Work during the COVID-19 Pandemic:

A Two-Pronged Approach. International Studies in Educational Administration 48, 3: 38 - 44.

Prew, M. 2018. School-Based Management in Secondary Education in Sub-

Saharan Africa. Johannesburg: Witwatersrand University Press.

https://doi.org/10.15868/socialsector.36894

Republic of South Africa 1993. South African Interim Constitution, Act No. 200 of 1993. Pretoria: Government Printers.

Republic of South Africa 1996a. South African Constitution Act, No. 108 of 1996. Pretoria: Government printers.

Republic of South Africa 1996b. National Education Policy Act, No. 27 of 1996. Pretoria: Government Printers.

Republic of South Africa 1996c. The South African Schools Act, No. 84 of 1996. Pretoria: Government Printers.

Republic of South Africa 2006. Amended National Norms and Standards for School Funding. Government Gazette, 29179(869). Pretoria: Government Printers.

Republic of South Africa 2008. Amended National Norms and Standards for

School Funding. Government Gazette, 31496(1087). Pretoria: Government Printers.

Sayed, Y. 1997. Understanding Educational Decentralisation in Postapartheid South Africa. Journal of Negro Education 66,4: 354 - 365. https://doi.org/10.2307/2668163

Sayed, Y. 2001. Post-apartheid Educational Transformation: Policy Concerns and Approaches. In Sayed, Y. \& J. Jansen (eds.): Implementing Education Policies: The South African Experience. Cape Town: UCT Press. 
Soudien, C., H. Jacklin \& U. Hoadley 2001. Policy Values: Problematising Equity and Redress in Education. In Sayed Y. \& J. Jansen (eds.): Implementing Education Policies: The South African Experience. Cape Town: UCT Press.

Spaull, N. 2013. South Africa's Education Crisis: The Quality of Education in South Africa, 1994 - 2011. Johannesburg: Report Commissioned by Centre for Development and Enterprise.

https://doi.org/10.4102/sajce.v10i1.924

Spaull, N. \& S. van der Berg 2020. Counting the Cost: COVID-19 School Closures in South Africa and its Impact on Children. South African Journal of Childhood Education 10,1: 13.

Steyn, H.J., S.C. Steyn \& E.A.S. de Waal 2001. The South African Education System: Core Characteristics. Noordbrug: Keurkopié.

Tabak, I. 2006. Prospects for Change at the Nexus of Policy and Design. Educational Researcher 35: 24 - 30.

https://doi.org/10.3102/0013189X035002024

Teja, N.D. 2020. Decentralisation and the Territorial Development: An Analysis of 3-Capital Model in Andhra Pradesh. Indian Journals.com 8, 2: 140 - 164 .

Taylor, N., G. Wills \& U. Hoadley 2019. Addressing the 'Leadership Conundrum' through a Mixed Method Study of School Leadership for Literacy. Research in Comparative and International Education 4,1: 30 - 53. https://doi.org/10.1177/1745499919828928

Toyana, M. 2020. Schools Reopen in South Africa as Parents Worry about Safety. Reuters. Available at: https://www.reuters.com/article/ukhealth-coronavirus-safrica-education-idUKKBN23F26H (Accessed on 23 October 2020.)

United Nations Children's Fund. 2020. Mitigating the Effects of COVID-19 Pandemic on Food and Nutrition of School Children. United Nations. Available at:

https://www.unicef.org/media/68291/file/Mitigating-the-Effects-ofthe-COVID-19-Pandemic-on-Food-and-Nutrition-of-schoolchildren.pdf (Accessed on 4 February 2021.)

Van der Berg, S. 2008. Poverty and Education. Education Policy Series 10: 28.

Veriava, F., A. Thom \& T.F. Hodgson 2017. Basic Education Rights Handbook: Education Rights in South Africa. The Preface. Available 
at: https://www.worldcat.org/title/basic-education-rights-handbookeducation-rights-in-south-africa/oclc/979988287

(Accessed on 8 February 2021.)

von Fintel, M., A. Zoch \& S. Van der Berg 2017. The Dynamics of Child Poverty in South Africa between 2008 and 2012. Child Indicators Research 10,4: 945 - 969.

https://doi.org/10.1007/s12187-016-9393-z

Wadesango, N., S. Rembe \& O. Chabaya 2010. An Analysis of the Type of Teachers that Participate in Decision-making in Schools: A Case Study of Gweru District Secondary Schools in Zimbabwe. International Studies in Educational Administration 38, 2: 5 - 20.

Thamsanqa Thulani Bhengu Academic Leader: Doctoral Studies

School of Education University of KwaZulu-Natal Durban Bhengutt@ukzn.ac.za 